\title{
GANGGUAN MEMORI EPISODIK PADA EPILEPSI LOBUS TEMPORAL DAN NONTEMPORAL
}

\author{
EPISODIC MEMORY DISORDER IN TEMPORAL AND NONTEMPORAL LOBE \\ EPILEPSY
}

Clara Krishanti Koestoer, * Aris Catur Bintoro, * Dwi Pudjonarko*

\section{ABSTRACT}

Introduction: Memory is the most defected cognitive function in neurological problems including epilepsy. Amnesia, refers to episodic memory impairment (EMI), which components are regulated by various areas related to brain lobes especially the temporal lobe. EMI represents a major cognitive component in temporal lobe epilepsy (TLE) but also encounter in focal epilepsy outside the temporal lobe.

Aim: To prove the difference between EMI that occurs in TLE and nontemporal lobe epilepsy (NTLE) patients.

Method: A cross-sectional study on epilepsy patients in Neurology Clinic of dr. Kariadi Hospital, Semarang from November 2016 until January 2017. Subjects were devided into TLE and NTLE group based on clinical semiology and electroencephalography (EEG). Interviews and questionnaires were done to the characteristics of subjects which can aggravate EMI, and memory tests was performed using Word List Memory Task, Word List Memory Recall, and Word List Memory Recognition. Statistical analysis using Chi-square test and multivariate logistic regression.

Results: Subjects obtained were 43 respondents consisting of 21 TLE and 22 NTLE subjects. Significant difference of EMI occurrence was shown in TLE compared to NTLE, especially on delayed recall component. Patients with history of epilepsy $>10$ years tend to have a significant EMI, while patients with first seizure $>10$ years old do not tend to have EMI with or without other confounding factors.

Discussion: There are differences in the occurrence of EMI on the TLE and NTLE independently, especially delayed recall.

Keywords: Episodic memory impairment, temporal lobe epilepsy

\section{ABSTRAK}

Pendahuluan: Memori merupakan fungsi kognitif yang paling rentan terkena gangguan neurologis termasuk epilepsi. Salah satunya adalah amnesia, merujuk pada gangguan memori episodik (GME) yang komponennya diatur oleh berbagai area terkait lobus otak terutama lobus temporal. Gangguan memori episodik (GME) mewakili komponen kognitif utama pada epilepsi lobus temporal (ELT), namun juga tidak jarang ditemui pada epilepsi fokal di luar lobus temporal. (ELNT).

Tujuan: Mengetahui perbedaan GME pada penderita epilepsi lobus temporal dengan epilepsi lobus nontemporal

Metode: Penelitian potong lintang terhadap pasien epilepsi yang berobat ke Poli Saraf RSUP dr. Kariadi, Semarang pada bulan November 2016 hingga Januari 2017. Subjek dikelompokkan menjadi ENT dan ELNT berdasarkan gambaran semiologi klinis dan elektroensefalografi (EEG). Dilakukan wawancara dan pemakaian kuesioner terhadap karakteristik subjek yang dapat memperberat GME, serta tes memori menggunakan Word List Memory Task, Word List Memory Recall, dan Word List Memory Recognition. Analisis statistik menggunakan uji Chi-square dan uji multivariat dengan regresi logistik.

Hasil: Didapatkan 43 subjek yang terdiri dari 21 subjek ELT dan 22 subjek ELNT. Didapatkan subjek yang mengalami GME pada ELT lebih banyak secara bermakna dibandingkan ELNT, terutama pada komponen delayed recall. Subjek yang menderita epilepsi $>10$ tahun cenderung mengalami GME secara bermakna, sedangkan subjek yang mengalami serangan awal pada usia $>10$ tahun lebih cenderung tidak mengalami GME, baik secara independen maupun bersama-sama dengan faktor perancu yang lain.

Diskusi: Terdapat perbedaan terhadap terjadinya GME pada ELT dan ELNT secara independen, terutama pada komponen delayed recall.

Kata kunci: Epilepsi lobus temporal, gangguan memori episodik

*Bagian/SMF Ilmu Penyakit Saraf FK Universitas Diponegoro/RSUP Dr. Kariadi, Semarang. Korespondensi: soekarnohattasoeha@ hotmail.com. 


\section{PENDAHULUAN}

Epilepsi dapat merugikan dan memengaruhi beberapa aspek dari fungsi sehari-hari yang mengarah pada gangguan komponen kognisi, status emosionalperilaku, dan perilaku sosial adaptif. ${ }^{1}$ Jenis epilepsi fokal yang paling banyak ditemukan pada orang dewasa adalah epilepsi lobus temporal (ELT), yaitu regio epileptogenik yang terlibat antara lain struktur mesial lobus temporal, terutama hipokampus, amigdala, girus parahipokampus. ${ }^{2}$ Pada penelitian oleh Semah dkk terhadap 2200 pasien epilepsi, sebanyak 66\% memiliki epilepsi temporal. ${ }^{3}$

Istilah amnesia mengacu pada sebagian atau total kehilangan ingatan atau memori dan bisa disebabkan oleh kerusakan otak organik dan/atau berbagai bentuk tekanan psikologis. Hilangnya ingatan bisa memengaruhi kejadian atau pengalaman yang terjadi baik setelah timbulnya gangguan (amnesia anterograd) atau yang terjadi sebelum gangguan (amnesia retrograd). Sementara itu, amnesia paling sering terjadi untuk kejadian autobiografi pribadi (memori episodik), walaupun ada beberapa pasien yang juga menunjukkan hilangnya pengetahuan faktual tentang dunia (memori semantik). ${ }^{4}$

Memori episodik didefinisikan sebagai kemampuan untuk memperoleh dan mengambil kembali informasi baru yang terkait ruang dan waktu. Area otak yang terkait dengan memori episodik adalah lobus temporal medial, lobus frontal, serta area lain (lobus parietal yang berperan terhadap detail dan korteks retrosplenial). Memori episodik yang merupakan komponen esensial dalam membangun kesinambungan dan identitas biografi, secara ontogenetik berkembang paling terakhir serta paling rentan terhadap kerusakan otak. ${ }^{5}$

Sebagian besar penelitian memori episodik dilakukan terhadap penuaan, kerusakan kognitif ringan, dan gangguan degeneratif otak, sementara investigasi terhadap epilepsi lebih sedikit. Hal ini akan berkontribusi terhadap penilaian keluhan memori sehari-hari dalam pendekatan etiologis serta peran lobus temporal medial. ${ }^{6-9}$ Namun belum diketahui perbandingan berat dan banyaknya gangguan memori episodik pada penderita ELT dan epilepsi lobus nontemporal (ELNT), sehingga perlu dilakukan penelitian ini.

\section{TUJUAN}

Mengetahui perbedaan bermakna terhadap gangguan memori episodik pada penderita epilepsi lobus temporal dengan epilepsi lobus nontemporal.

\section{METODE}

Penelitian observasional dengan rancangan potong lintang yang dilaksanakan di ruang Poliklinik Saraf RSUP dr. Kariadi, Semarang, pada bulan November 2016 hingga bulan Januari 2017. Kriteria inklusi adalah pasien epilepsi $>5$ tahun dan minimal tamat sekolah dasar, serta kriteria eksklusi memiliki riwayat infeksi SSP, tumor otak, cedera kepala berat, atau gangguan psikiatri.

Pengambilan data dilakukan dengan identifikasi karakteristik subjek, skrining dengan Mini Mental State Examination (MMSE), dilanjutkan penilaian memori menggunakan tes Word List Memory Task (WLMT), Word List Memory Recall (WLMRec), dan Word List Memory Recognition (WLMRcg). Jenis epilepsi (ELT dan ELNT) ditentukan melalui gambaran semiologi bangkitan dan elektroensefalografi (EEG).

Frekuensi atau banyaknya serangan bangkitan yang terjadi selama satu tahun terakhir kami kelompokkan menjadi banyaknya serangan dengan frekuensi tinggi/berat ( $\geq 1 \mathrm{x} /$ minggu), sedang $(\geq 1 \mathrm{x} /$ bulan), dan rendah/ringan ( $\geq 1 \mathrm{x} /$ tahun).

Gangguan memori episodik (GME) disepakati sebagai amnesia short-term yang mengarah kepada kemampuan penderita untuk menyimpan dan mengingat data mengenai rentang waktu (hitungan menit-jam) dan aspek, dites dengan sistem skoring 3 tools yang saling berkesinambungan untuk menentukan gangguan pada komponen memori episodik, antara lain immediate/free recall, delayed recall, dan atau recognition. ${ }^{10}$ Salah satu saja dari tools tersebut bernilai di bawah rentang skor normal ( $<60 \%$ nilai maks), maka dikatakan memiliki GME. WLMT jika skor $<17$ (free recall), WLMRec jika skor $<6$ (delayed recall), dan WLMRcg jika skor $<8$ (recognition). ${ }^{11}$

Penelitian ini telah mendapatkan persetujuan dari Komisi Etik Fakultas Kedokteran Universitas Diponegoro/RSUP Dr. Kariadi, Semarang. Data dianalisis menggunakan program SPSS 22.0 for 
Windows. Dilakukan uji Chi-square dan Pearson, serta analisis multivariat dengan regresi logistik. Hasil dikatakan bermakna bila $\mathrm{p}<0,05$.

\section{HASIL}

Didapatkan 43 subjek yang terdiri dari 21 subjek ELT dan 22 subjek ELNT (Tabel 1), dengan mayoritas perempuan $(52,4 \%$ vs $59,1 \%)$, berusia muda (21-30 tahun), dan mengalami serangan pada usia $>10$ tahun $(61,9 \%$ dan $68,2 \%)$ pada kedua kelompok. Pada kelompok ELT, sebagian besar subjek menderita epilepsi $>10$ tahun $(61,9 \%)$ dan menggunakan obat antiepilepsi (OAE) politerapi (81\%). Adapun pada kelompok ELNT, didapatkan proporsi yang hampir sama antara subjek yang mengalami epilepsi $\leq 10$ dan $>10$ tahun, serta yang mendapatkan monoterapi dan politerapi.

Tabel 1. Karakteristik Subjek pada kelompok ELT dan ELNT $(n=43)$

\begin{tabular}{lcc}
\hline \multirow{2}{*}{ Variabel } & ELT (n=21) & ELNT (n=22) \\
\cline { 2 - 3 } Umur & $\mathbf{n}(\mathbf{\%})$ & $\mathbf{n}(\mathbf{\%})$ \\
- $11-20$ & $5(23,8)$ & $5(22,7)$ \\
- $21-30$ & $8(38,1)$ & $10(45,5)$ \\
- $31-40$ & $4(19)$ & $3(13,6)$ \\
- $41-50$ & $4(19)$ & $4(18,2)$ \\
Jenis kelamin & & \\
- Laki-laki & $10(47,6)$ & $9(40,9)$ \\
- Perempuan & $11(52,4)$ & $13(59,1)$ \\
Lama menderita & & \\
epilepsi & & \\
- $\leq 10$ tahun & $8(38,1)$ & $12(54,5)$ \\
- $>10$ tahun & $13(61,9)$ & $10(45,5)$ \\
Usia onset pertama & & \\
- $\leq 10$ tahun & $8(38,1)$ & $7(31,8)$ \\
- >10 tahun & $13(61,9)$ & $15(68,2)$ \\
Frekuensi & & \\
- Ringan & $5(23,8)$ & $9(40,9)$ \\
- Sedang & $11(52,4)$ & $12(54,5)$ \\
- Berat & $5(23,8)$ & $1(4,5)$ \\
Obat anti epilepsi & & \\
- Monoterapi & $4(19)$ & $10(45,5)$ \\
- Politerapi & $17(81)$ & $12(54,5)$ \\
\hline
\end{tabular}

*Uji Chi-square; ELT: epilepsi lobus temporal; ELNT: epilepsi lobus nontemporal.
Terdapat perbedaan bermakna $(p=0,044)$ antara subjek yang mengalami GME pada kelompok ELT dan ELNT berdasarkan uji Chi-square (Tabel 2). Demikian pula perbedaan yang bermakna $(p=0,048)$ pada hasil WLMRec, bahwa subjek dengan ELT lebih banyak mengalami gangguan dibandingkan kelompok ELNT.

Tabel 3 menunjukkan subjek yang menderita epilepsi $>10$ tahun cenderung mengalami GME secara bermakna $(p=0,01)$, sedangkan subjek yang mengalami serangan awal pada usia $>10$ tahun lebih cenderung tidak mengalami GME $(p=0,03)$. GME lebih banyak terjadi pada subjek dengan ELT dibandingkan ELNT secara bermakna $(p=0,04)$.

Pada analisis multivariat faktor perancu dan kelompok independen terhadap GME, dilakukan analisis regresi logistik. Didapatkan lama menderita dan usia awitan berpengaruh memperberat GME secara bermakna $(\mathrm{p}=0,013$ dan $\mathrm{p}=0,005)$, sedangkan jenis epilepsi sebagai variabel utama yang diteliti didapatkan tidak bermakna (Tabel 3).

\section{PEMBAHASAN}

Penelitian ini mendapatkan mayoritas subjek berusia muda (11-30 tahun), sesuai dengan studi sebelumnya, dan mayoritas jenis kelamin hampir sama di kedua kelompok..$^{23}$

Pada penderita epilepsi terdapat faktor-faktor perancu yang merupakan bagian karakteristik subjek dan sekaligus dapat mengaburkan signifikansi dari peran topis epilepsi terhadap GME. Oleh karena itu dilakukan analisis bivariat yang menunjukkan bahwa subjek yang menderita epilepsi selama $\geq 10$ tahun $(\mathrm{p}=0,010)$, usia awitan pertama $<10$ tahun $(\mathrm{p}=0,003)$, dan pengobatan politerapi $(p=0,012)$ merupakan perancu yang berpengaruh langsung terhadap GME. Namun ketiga variabel tidak berpengaruh bermakna $(p \geq 0,05)$ terhadap fokus epileptogenik pada kelompok ELT dan ELNT.

Temuan ini telah diungkapkan juga pada studistudi sebelumnya, bahwa risiko GME meningkat pada penderita epilepsi yang kronik dengan lama menderita epilepsi $\geq 10$ tahun (dibandingkan dengan kronisitas 5-10 tahun), pada usia awitan bangkitan pertama $<10$ tahun (dibandingkan dengan yang usia $>10$ th), dan pada penggunaan OAE politerapi 
Tabel 2. Gangguan Memori Episodik pada Kelompok ELT dan ELNT (n=43)

\begin{tabular}{lccccc}
\hline \multirow{2}{*}{ Variabel } & $\begin{array}{c}\text { ELT } \\
(\mathbf{n = 2 1})\end{array}$ & $\begin{array}{c}\text { ELNT } \\
(\mathbf{n = 2 2})\end{array}$ & $\mathbf{p}$ & RO & IK 95\% \\
\cline { 2 - 3 } & $\mathbf{n}(\mathbf{\%})$ & $\mathbf{n}(\mathbf{\%})$ & & & \\
\hline WLMT & & & & & \\
- $<17$ & $7(33,3)$ & $2(9,1)$ & 0,069 & 5,000 & $0,90-27,74$ \\
- $\geq 17$ & $14(66,7)$ & $20(90,9)$ & & & \\
WLMRec & & & & & \\
- $<6$ & $13(61,9)$ & $7(31,8)$ & $0,048^{*}$ & 3,482 & $0,99-12,24$ \\
- $\geq 6$ & $8(38,1)$ & $15(68,2)$ & & & \\
WLMRcg & & & & & \\
- $<8$ & $3(14,3)$ & $4(18,2)$ & 1,000 & 0,750 & $0,14-3,84$ \\
- $\geq 8$ & $18(85,7)$ & $18(81,8)$ & & & \\
GME & & & & & \\
- Ya & $15(71,4)$ & $9(40,9)$ & $0,044 *$ & 3,611 & $1,01-12,89$ \\
- Tidak & $6(28,6)$ & $13(59,1)$ & & & \\
\hline
\end{tabular}

*Signifikan p<0,05; WLMT: Word List Memory Task; WLMRec: Word List Memory Recall; WLMRcg: Word List Memory Recall; GME: Gangguan memori episodik; RO: rasio Odds; IK: interval kepercayaan.

(dibandingkan dengan yang monoterapi). ${ }^{16-17,20}$ Pada kerangka teori, salah satu karakteristik epilepsi yang berpengaruh pada GME disebutkan beratnya serangan. Namun berat serangan diabaikan karena tidak diukur. ${ }^{21}$ Tentunya hal ini menjadi salah satu keterbatasan pada penelitian kami.

Untuk kognitif global hasil MMSE seluruh subjek adalah baik $(>24)$. Subjek ELT mengalami GME lebih banyak (71\%) dibandingkan pada kelompok ENLT $(40,9 \%)$ secara bermakna $(\mathrm{p}=0,044)$. Perbedaan ini juga terutama pada tes WLMRec $(\mathrm{p}=0,048)$, yaitu delayed recall. Hal ini sesuai dengan Takayama dan Bero pada penelitian observasionalnya yang menyatakan bahwa komponen memori yang lebih dulu rusak duluan dan paling sensitif pada skrining gangguan kognitif adalah delayed recall verbal atau visual. ${ }^{24-25}$

Beberapa literatur telah menyatakan bahwa keseragaman sampel amat berperan dalam menarik suatu hipotesis yang valid. ${ }^{12,14,21}$ Setelah dilakukan analisis multivariat ternyata jenis epilepsi (ELT dan ELNT) tidak lagi menjadi pembeda GME yang bermakna pada penderita epilepsi $(p=0,47)$, namun lama menderita dan usia awitan epilepsi yang merupakan faktor risiko terjadinya GME. Suatu penelitian mengenai dampak lamanya menderita epilepsi terhadap kognitif menyatakan bahwa lama mengidap epilepsi hingga lebih dari 10 tahun merupakan salah satu faktor resiko prediktor kondisi kognitif yang lebih buruk, yaitu 1-2x daripada penderita dengan lama $<10$ tahun..$^{16,24}$

Lama menderita juga secara tidak langsung memengaruhi penurunan fungsi memori, antara lain: durasi, frekuensi, dan tipe bangkitan, riwayat OAE, serta level intelektual. ${ }^{14,16-17,19,26}$ Sulit untuk menganalisis lama menderita epilepsi terlepas dari karakteristik yang lain, kecuali jika sampel terdiri dalam jumlah besar atau jika karakteristik tersebut homogen. Pada penelitian ini hanya riwayat OAE dan frekuensi bangkitan yang terukur secara statistik, sehingga lama menderita $\geq 10$ tahun yang didapatkan sangat sedikit pengaruhnya terhadap GME.

Studi metaanalisis oleh Kim dan Ko menyatakan bahwa penderita epilepsi usia awitan masa kanak-kanak ( $<10$ tahun) mengalami gangguan kognitif yang lebih difus dan berat termasuk pada memori, namun dengan dominasi lebih pada intelektual. ${ }^{27}$ Pada penelitian ini didapatkan adanya pengaruh dari usia onset $<10$ tahun terhadap terjadinya GME, walaupun tidak melakukan observasi adanya gangguan intelektual. Hal ini sesuai dengan berbagai penelitian terdahulu yang juga 
Tabel 3. Uji Multivariat Regresi Logistik Faktor Perancu terhadap Gangguan Memori Episodik (n=43)

\begin{tabular}{|c|c|c|c|c|c|}
\hline \multirow{3}{*}{ Variabel } & \multicolumn{2}{|c|}{ GME } & \multicolumn{2}{|c|}{ Bivariat } & \multirow{3}{*}{$\begin{array}{c}\text { Multivariat } \\
\text { RO (IK 95\%) }\end{array}$} \\
\hline & Ya & Tidak & p* & $\mathrm{p}^{*}$ & \\
\hline & n (\%) & n (\%) & & & \\
\hline \multicolumn{6}{|c|}{ Lama menderita epilepsi } \\
\hline - $>10$ tahun & $17(70,8)$ & $6(31,6)$ & 0,010 & $\mathbf{0 , 0 1 3}$ & $0,034(0,002-0,496)$ \\
\hline - $\leq 10$ tahun & $7(29,2)$ & $13(68,4)$ & & & \\
\hline \multicolumn{6}{|l|}{ Usia onset pertama } \\
\hline - $\leq 10$ th & $13(54,2)$ & $2(10,5)$ & 0,003 & 0,005 & $0,010(0,000-0,245)$ \\
\hline - $>10$ th & $11(45,8)$ & $17(89,5)$ & & & \\
\hline \multicolumn{6}{|l|}{ Frekuensi serangan } \\
\hline - Berat & $5(20,8)$ & $1(5,3)$ & 0,247 & 0,100 & $0,135(0,013-1,463)$ \\
\hline - Sedang & $13(54,2)$ & $10(52,6)$ & & & \\
\hline - Ringan & $6(25)$ & $8(42,1)$ & & & \\
\hline \multicolumn{6}{|l|}{ Obat antiepilepsi } \\
\hline - Politerapi & $20(83,3)$ & $9(47,4)$ & 0,012 & 0,098 & $0,123(0,010-1,476)$ \\
\hline - Monoterapi & $4(16,7)$ & $10(52,6)$ & & & \\
\hline \multicolumn{6}{|l|}{ Jenis epilepsi } \\
\hline - ELT & $15(71,4)$ & $9(40,9)$ & 0,044 & 0,470 & $0,440(0,047-4,078)$ \\
\hline - ELNT & $6(28,6)$ & $13(59,1)$ & & & \\
\hline
\end{tabular}

*Uji Chi-square; GME: gangguan memori episodik; RO: rasio Odds; IK: interval kepercayaan.

mengungkapkan adanya gangguan memori pada usia awitan $<10$ tahun, yang disertai gangguan pada domain kognitif lainnya. ${ }^{6,14,17,28}$

Karakteristik yang memiliki pengaruh paling kuat terhadap terjadinya GME terdapat pada frekuensi bangkitan yang tinggi yang diamati dalam batasan setahun terakhir sebelum analisis, diikuti oleh usia awitan awal, lama menderita epilepsi, dan penggunaan politerapi OAE. ${ }^{26}$ Demikian pula Allebone dkk menyatakan bahwa karakteristik terkuat dalam menyebabkan GME diperankan oleh usia awitan dini, diikuti dengan lama menderita epilepsi dan politerapi OAE. ${ }^{29} \mathrm{Hal}$ ini hampir sama dengan penelitian ini signifikansi lama menderita $(\mathrm{p}=0,004)$ lebih tinggi dibandingkan usia awitan $(p=0,014)$, sedangkan politerapi tidak berpengaruh.

Penelitian terdahulu menyatakan bahwa epilepsi akan menurunkan beberapa fungsi dari kognitif global dan domain memori merupakan fungsi yang paling sering dan rentan terkena. ${ }^{3-4}$ Hussein dan Shirin melakukan studi dalam membandingkan memori episodik pada ELT dan grup normal. Didapatkan ELT mesial merupakan epilepsi fokal yg paling dikaitkan dengan amnesia/ gangguan memori episodik, karena meliputi hampir $50 \%$ dari seluruh epilepsi fokal dan paling banyak mengakibatkan kejang refrakter, sehingga banyak dilakukan penelitian terhadap memori episodik pre dan pascaoperasi ELT. Pada penelitian ini didapatkan perbedaan terhadap GME pada ELT yang lebih mungkin terjadi jika dibandingkan pada ELNT. Belum ada penelitian sebelumnya mengenai ini, namun berbagai studi mengenai pusat utama komponen memori episodik berada sebagian besar pada lobus mesial temporal. ${ }^{30-35}$

Adanya beberapa ketidaksesuaian pada penelitian ini dimungkinkan karena jumlah subjek yang masih kurang banyak dengan adanya karakteristik penderita sebagai faktor perancu yang heterogen, serta adanya overlapping diagnosis atau bahkan jenis epilepsi fokal itu sendiri, sehingga pada analisis multivariat tidak didapatkan hubungan antara kelompok jenis epilepsi dengan terjadinya GME. Overlapping ini dapat diminimalisir dari gambaran MRI, yaitu epilepsi akibat meluasnya kerusakan hingga lebih dari satu lobus (walaupun epileptogenik hanya nampak dominan pada 1 lobus saja), sebaiknya dieksklusikan. 
Penelitian ini mempunyai keterbatasan, antara lain tidak dianalisis beratnya serangan yang juga merupakan karakteristik perancu, ketidaklengkapan data imajing berupa MRI untuk membantu menegakkan diagnosa jenis epilepsi yang lebih akurat. Demikian pula karakteristik minor lainnya yang tidak diukur namun dapat memengaruhi variabel dependen, seperti tipe kejang, durasi kejang, dan rentang pendidikan tertentu.

\section{KESIMPULAN}

Terdapat perbedaan gangguan memori episodik pada epilepsi lobus temporal dan epilepsi lobus nontemporal, terutama pada komponen delayed recall. Lama menderita epilepsi $\geq 10$ tahun dan usia onset bangkitan pertama $<10$ tahun akan memengaruhi GME, baik secara independen maupun bersama-sama dengan faktor perancu yang lain.

\section{DAFTAR PUSTAKA}

1. World Health Organization. Epilepsy. WHO [serial online]. 2017 [diunduh 5 Oktober 2017]. Tersedia dari: WHO Media Centre.

2. Blair RD. Temporal lobe epilepsy semiology. Epilepsy Res Treatment. 2012:2012:751510.

3. Semah F, Picot MC, Adam C, Broglin D, Bazin B, Baulac M, dkk. Is the underlying cause of epilepsy a major prognostic factor for recurrence? Neurology. 1998;(51):1256-62.

4. Simons JS, Graham KS. Amnesia. Dalam: Fink G. Encyclopedia of stress. Academic Press: San Diego; 2000. h.176-8.

5. Matthews BR. Memory dysfunction. Continuum. 2015;21(3):613-26.

6. Skirrow C, Cross JH, Harrison S, Cormack F, Harkness W, Coleman R, dkk. Temporal lobe surgery in childhood and neuroanatomical predictors of long-term declarative memory outcome. Brain. 2015;138(1):80-93.

7. Jehi L. Prediction and prevention of verbal memory decline after temporal lobectomy. Epilepsy Curr. 2014;14(1):19-21.

8. Voltzenlogel V, Despres O, Vignal JP, Hirsch E, Manning L. The influence of seizure frequency on anterograde and remote memory in mesial temporal lobe epilepsy. Seizure. 2014;23(9):792-8.

9. Múnera CP, Lomlomdjian C, Gori B, Terpiluk V, Medel N, Solis P, dkk. Episodic and semantic autobiographical memory in temporal lobe epilepsy. Epilepsy Res Treat. 2014;2014:157452.
10. Gavett BE, Horwitz JE. Immediate list recall as a measure of short-term episodic memory: insights from the serial position effect and item response theory. Arch Clin Neuropsychol. 2012;27(2):125-35.

11. Hutcherson L, Sanford C, Herz G, Harter G, Torres I. Memory assessment scales. Psychol Assess Resour. 1990;1-103.

12. Miller LA, Galioto R, Tremont G, Davis J, Bryant $\mathrm{K}$, Roth J, dkk. Cognitive impairment in older adults with epilepsy: characterization and risk factor analysis. Epilepsy and Behavior. 2016:56;113-7.

13. Helmstaedter C. Cognitive outcomes of different surgical approaches in temporal lobe epilepsy. Epileptogie. 2016;33:21-37.

14. Smith ML. Epilepsy and cognition. Dalam: Prasher VP, Kerr M, editor. Epilepsy and Intellectual Disabilities. New York: Springer; 2008. h. 193-208.

15. Gauffin H. Medical outcome in epilepsy patients of young adulthood-A 5-year follow-up study. Seizure. 2012;18(4):293-7.

16. Loughman A, Bowden SC, D'Souza WJ. A comprehensive assessment of cognitive function in the common genetic generalized epilepsy syndromes. European J Neurol. 2016;(0):1-8.

17. Rayner G, Jackson GD, Wilson SJ. Mechanisms of memory impairment in epilepsy depend on age at disease onset. Neurology. 2016;87(16):1642-49.

18. Merkena MD. Prevalence of cognitive adverse outcomes in epileptic outpatients. J Neurol \& Stroke. 2015;4(5):00155.

19. Abde-Hakeem N, Hassan MM, Mostafa YH, Shaban I, Tohami A. Assessment of the cognitive function in the epileptic patients and effect of anti epileptic drugs. J Biol, Agriculture and Healthcare. 2014;4(27):26975.

20. Helal SI, Megahed HS, Salem SM, Youness ER. Monotherapy versus polytherapy in epileptic adolescents. Macedonian Journal of Medical Sciences. 2013;6(2):174-7.

21. Lodhi S, Agrawal N. Neurocognitive problems in epilepsy. Advances in Psychiatric Treatment. 2012;(18):232-40.

22. Vozikis A, Goulionis JE, Nikolakis D. Risk factors associated with epilepsy: a case-control study. Heal Sci J. 2012;6(3):509-17.

23. Savic I, Jerome EJ. Structural and functional correlates of epileptogenesis-does gender matter? Neurobiol Dis. 2014;70:69-73.

24. Takayama Y. A delayed recall battery as a sensitive screening for mild cognitive impairment: follow-up study of memory clinic patients after 10 years. J Med Dent Sci. 2010;57(2):177-84. 
25. Bero AW, Meng J, Cho S, Shen A-H, Canter $\mathrm{RG}$, Ericsson M, dkk. Early remodeling of the neocortex upon episodic memory encoding. PNAS. 2014;111(32):11852-57.

26. Engman E, Malmgren K. Long-term follow-up of memory in patients with epilepsy. Dalam: Zeman A, Kapur M, Jones-Gotman M, editor. Epilepsy and Memory. 2008;2(5):83-101.

27. Kim E, Ko T. Cognitive impairment in childhood onset epilepsy: up-to-date information about its causes. 2016;59(4):155-64.

28. Kernan CL, Asarnow R, Siddarth P, Gurbani S, Lanphier EK, Sankar R, dkk. Neurocognitive profiles in children with epilepsy. Epilepsia. 2012;53(12):2156-63.

29. Allebone J, Rayner G, Siveges B, Wilson SJ. Altered self-identity and autobiographical memory in epilepsy. Epilepsia. 2015;56(12):1982-91.

30. Centeno M, Vollmar C, O’Muircheartaigh J, Stretton J, Bonelli SB, Symms MR, dkk. Memory in frontal lobe epilepsy: an fMRI study. Epilepsia. 2012;53(10):1756-64.
31. Eichenbaum H, Sauvage M, Fortin N, Komorowski R, Lipton P. Towards a functional organization of episodic memory in the medial temporal lobe. Neuroscience and Neurobehav Rev. 2012;36(7):1597608.

32. Foster BL, Rangarajan V, Shirer WR, Parvizi J. Intrinsic and task-dependent coupling of neuronal population activity in hyman parietal cortex. Neuron Cell Press. 2015;86(2):578-90.

33. Knopman AA, Wong CH, Stevenson RJ, Homewood J, Mohamed A, Somerville E, dkk. The cognitive profile of occipital lobe epilepsy and the selective association of left temporal lobe hypometabolism with verbal memory impairment. Epilepsia. 2014;55(8):e80-4.

34. Helmstaedter C. The impact of epilepsy on cognitive function. J Neurol, Neurosurg Psych. 2013;84(9):5-15.

35. Bonelli SB, Thompson PJ, Yogarajah M, Powell RHW, Samson RS, McEvoy AW, dkk. Memory reorganization following anterior temporal lobe resection: a longitudinal functional MRI study. Brain. 2013;136(6):1889-900. 